\title{
Wildlife vertebrate mortality in roads from Santa Fe Province, Argentina
}

\section{Mortalidad de vertebrados en caminos de la provincia de Santa Fe, Argentina}

\author{
Andrés M. Attademo ${ }^{1,2 *}$, Paola M. Peltzer ${ }^{1,2}$, Rafael C. Lajmanovich ${ }^{1,2}$, Gustavo Elberg ${ }^{2}$, Celina Junges ${ }^{1,2}$, \\ Laura C. Sanchez ${ }^{1,3}$ and Agustín Bassó ${ }^{2}$ \\ ${ }^{I}$ National Council for Scientific and Technical Research (CONICET), Paraje el Pozo s/n (3000), Santa Fe, Argentina. \\ ${ }^{2}$ Faculty of Biochemistry and Biological Sciences ESS- FBCB-UNL, Paraje el Pozo s/n (3000), Santa Fe, Argentina. \\ ${ }^{3}$ Centre of Scientific Investigation and Transference of Technology to the Production (CICYTTP), Materi and España s/n (3105), Diamante, Entre Rios, \\ Argentina. \\ *Correspondent: mattademo@hotmail.com
}

\begin{abstract}
Mortality of vertebrates was monitored on 2 roads (National Road 168; NR168 and Provincial Road 1; PR1) in Santa Fe Province (Argentina) from October 2007 to August 2008. These roads differed in traffic volume and surrounding landscape management conditions. We also investigated the influence of environmental variables (mean monthly air temperature and monthly total rainfall) on the incidence of road kills. Two people monitored the roads on foot (1 000-m line transects), 3 times a month (36 samples per road). We found 2024 vertebrate road killed specimens representing 61 species ( 7 amphibians, 15 reptiles, 32 birds, and 7 mammals). The toad Rhinella fernandezae was the most frequently killed species $(n=1307,64.57 \%)$. NR168 had a higher incidence of vertebrate road kills, particularity for amphibians, whereas birds had a higher incidence of road kills on PR1. We found a positive correlation between precipitation and temperature with vertebrate road kills on PR1. We suggest that vertebrate road mortality is a very serious problem for the conservation of the biodiversity in Santa Fe Province-Argentina, therefore implementing mitigation measures will be necessary.
\end{abstract}

Key words: road kills, vertebrate, Santa Fe, Argentina.

Resumen. Se estudió la mortalidad de vertebrados en 2 rutas (RP1: Ruta Provincial No 1 y RN168: Ruta Nacional No 168) de la Provincia de Santa Fe (Argentina) desde octubre de 2007 hasta agosto de 2008. Estas rutas diferían en el tránsito vehicular y obras de infraestructura. Además, se investigó la influencia de variables climáticas (temperatura media mensual y precipitación total mensual) con el atropellamiento de la fauna silvestre. Se realizaron de 2 a 3 transectos por mes de $1000 \mathrm{~m}$ cada uno, los cuales fueron recorridos a pie por 2 observadores. Un total de 2024 vertebrados fueron registrados distribuidos en 61 taxa (7 anfibios, 15 reptiles, 32 aves y 7 mamíferos). La especie más impactada fue el sapo Rhinella fernandezae $(n=1307,64.57 \%)$. La RN168 presentó una alta abundancia de vertebrados particularmente de anfibios, mientras que las aves fueron más representativas en la RP1. Se encontró una correlación positiva entre las variables ambientales (precipitación y temperatura) con la mortalidad de vertebrados en la RP1. Sugerimos que la mortandad de vertebrados en la Provincia de Santa Fe, Argentina, es un problema serio para la conservación de la biodiversidad, siendo necesaria la implementación de medidas de mitigación.

Palabras clave: mortalidad, rutas, vertebrados, Santa Fe, Argentina.

\section{Introduction}

Although road ecology is a recent science in South America, it is increasing rapidly with the public becoming aware of its relevance to the protection of wildlife populations. In general, the effects of roads on related aquatic and terrestrial ecosystems and wildlife are well documented, with changes reported in wildlife behavior, survival, and breeding density,

Recibido: 10 junio 2010; aceptado: 03 noviembre 2010 and in dispersal of exotic species (Foster and Humphrey, 1995; Newmark et al., 1996; Arroyave et al., 2006; Das et al., 2007; Row et al., 2007; Shwiff et al., 2007; Seshadri et al., 2009).. Accordingly, roads act as barriers or filters, causing habitat fragmentation and population isolation (Forman and Alexander, 1998; Trombulak and Frissell, 2000; Jaeger et al., 2005; Row et al., 2007; Shepard et al., 2008). Road edges also affect microclimate by producing changes in temperature and humidity, wind speed, and levels of solar radiation that can influence wildlife directly or through changes in the composition of roadside vegetation (Matlack, 1994). 
Traffic volume and density have greatly increased over the past 2 decades (Fahrig et al., 1995), producing road kill rates that exceed natural mortality (Ferreras et al., 1992), and affecting wild population densities (Fahrig et al., 1995; Huijser and Bergers, 2000), and sex structure (Gibbs and Steen, 2005). Diverse taxonomic groups are affected by vehicle collisions worldwide, including mammals (Clarke et al., 1998), birds (Erritzoe et al., 2003), reptiles (Bernardino and Dalrymple, 1992; Aresco, 2005; Shepard et al., 2008), amphibians (Fahrig et al., 1995; Hels and Buchwald, 2001; Glista et al., 2008), and invertebrates (Seibert and Conover, 1991; Mckenna et al., 2001). Likewise, this problem is widely suspected to play a role in vertebrate decline, particularly for amphibians (Blaustein and Wake, 1990; Gibbons et al., 2000; Ceballos and Ehrlich, 2002; Stuart et al., 2004, Glista et al., 2008).

In Argentina, despite the relatively dense paved and unpaved road network (38 $484 \mathrm{~km}$; DNV, 2001) and the growing number of vehicles (which increased approximately $22 \%$ between 2002 and 2007; DNRPA, 2010), issues related to the impact of roads and traffic on fauna have not been duly identified (Cairo and Zalba, 2007). The creation of the Southern Cone Common Market (MERCOSUR) accelerated the modification of natural environments. In view of the upcoming road network improvement and expansion in Argentina, it seems necessary to undertake comprehensive studies aimed at determining the extent of the effect of roads on vertebrate species.

Therefore, to understand the potential impacts of road on wildlife, we determined the spatial and temporal composition of road mortality of vertebrate species due to vehicle collision on 2 roads of Santa Fe Province (Argentina). Specifically, we answered these questions, 1), what are the groups of vertebrates most heavily impacted? 2), is there any variation in the composition of vertebrates killed according to traffic volume and surrounding landscape management? and $3)$, what is the influence of environmental variables (precipitation and temperature) on patterns of vertebrate mortality? Because vertebrates have been widely documented to be under negative pressure from multiple human threats worldwide, and road infrastructure plays a role in this process, studies like this and mitigation of vertebrate road kills have also become an essential conservation priority.

\section{Materials and methods}

Study area. The roads studied were located in the midwestern Santa Fe Province of Argentina (Fig. 1). The area belongs to the Espinal and Delta-Islas ecoregions (Burkart et al., 1999), with a mean annual temperature of $18^{\circ} \mathrm{C}$, and annual average precipitation of $800 \mathrm{~mm}$, mostly distributed in spring and summer. The area is dominated by wetlands, remnant of fluvial forests, and urban settlements. Recently, this area, together with the central region of Argentina, were considered the principal trade corridor of the region, optimizing trade and service flow between commercial centers in Argentina, Chile, Paraguay, and Uruguay (ANER, 2008).

Field survey. We selected 2 important roads situated in the floodplain of the Paraná River (Fig. 1). National Road $\mathrm{N}^{\mathrm{o}}$ 168 (NR168) is a two-lane road of intense traffic located near the Paraná River that connects 2 important urban areas: Santa Fe and Paraná cities. Mean daily traffic in 2008 ranged between 9500 and 10000 for heavy vehicles such as trucks and buses (El Litoral, 2008). The speed limit is $110 \mathrm{~km} / \mathrm{h}$; traffic flow is more important in summer than in winter. At present, the road is being enlarged; the project consists in constructing a new $7.30 \mathrm{~m}$-wide, concrete two-lane roadway with asphalt shoulders. For the construction and widening of this road, large amounts of soil and sand are being removed from the roadsides, producing a great local impact. The other road studied was Provincial Road No 1 (PR1) situated between Rincón and Los Zapallos localities (Santa Fe Province), which is characterized by its lower and more homogeneous vehicle flow throughout the year (generally increasing in summer) with a speed limit of $80 \mathrm{~km} / \mathrm{h}$. In 2007-2008, daily mean traffic was 2208 vehicles. The PR1 stretch selected runs across wetlands and lowlands, and was similar to NR168 in environmental characteristics and landscape structure. There are no plans to extend this road in the near future.

Animal data collection and environmental variables. We conducted road mortality detection surveys from October 2007 to September 2008. On each road (NR168 and PR1) stretch, we randomly projected trhee $1000-\mathrm{m}$ line transects and sampled each one 3 times per month $(\mathrm{N}=36$ samples per road). Two observers reviewed the road on foot to find dead bodies between 08:00 am and $12: 00 \mathrm{pm}$, with the aim of covering the entire road surface, focusing on roadsides. The surveyed roads were chosen based on human safety and accessibility (e.g., visibility and available shoulder). This intensive sampling was designed to enhance the detection of smaller carcasses (e.g., toads and frogs), because these animals are easily removed by vehicles due to rapid desiccation or by vertebrate scavengers (Hels and Buchwald, 2001). All road-killed vertebrates were identified to the lowest taxonomic category possible (e.g. Cei, 1980; Narosky and Yzurieta, 1993; Giraudo and Arzamendia, 1997; 


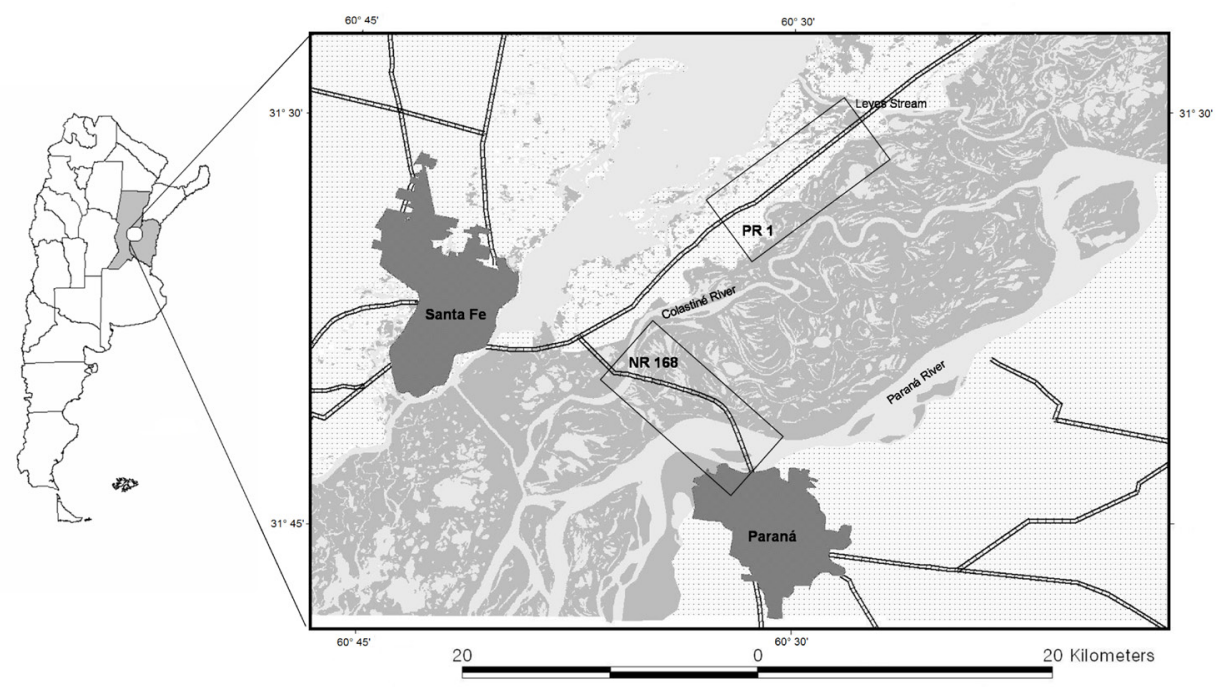

Figure 1. Location of sampling sites in central-eastern Argentina. Acronyms: National Road No 168 (NR168) and Provincial Road No 1 (PR1).

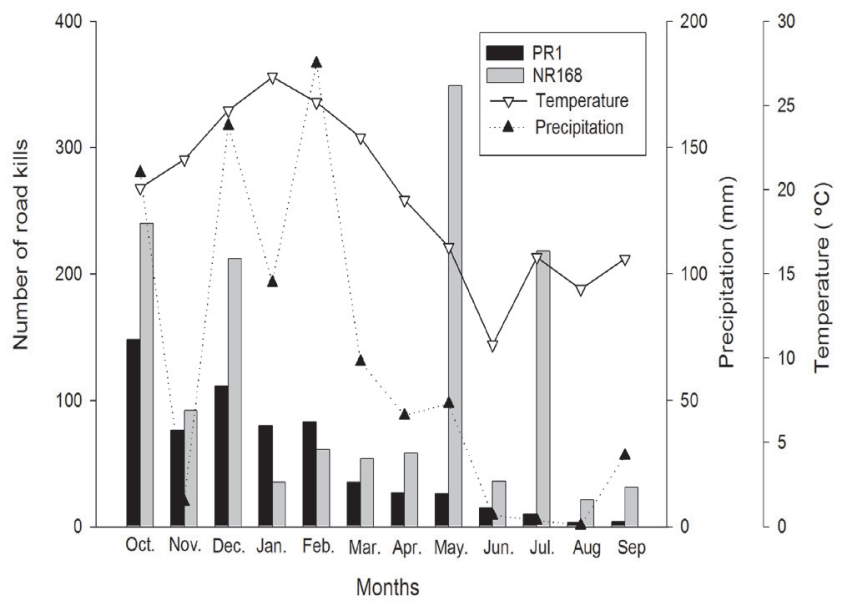

Figure 2. Road killed vertebrates vs. mean temperature and total precipitation per month on Provincial Road N ${ }^{\circ} 1$ (PR1) and National Road N ${ }^{\circ} 168$ (NR168) in Santa Fe Province, Argentina.

Cabrera, 1998; Canevari and Fernández Balboa, 2003). We transported all unidentified individuals in situ to the laboratory in labeled polyethylene bags for further identification. However, animals severely deteriorated on the road were included in the "non-identified" category. We removed all carcasses from the road or marked them with spray paint to avoid double counting.

We considered 2 environmental variables: mean monthly air temperature and monthly total rainfall levels (obtained from the meteorological station of the Universidad Nacional del Litoral, located approximately
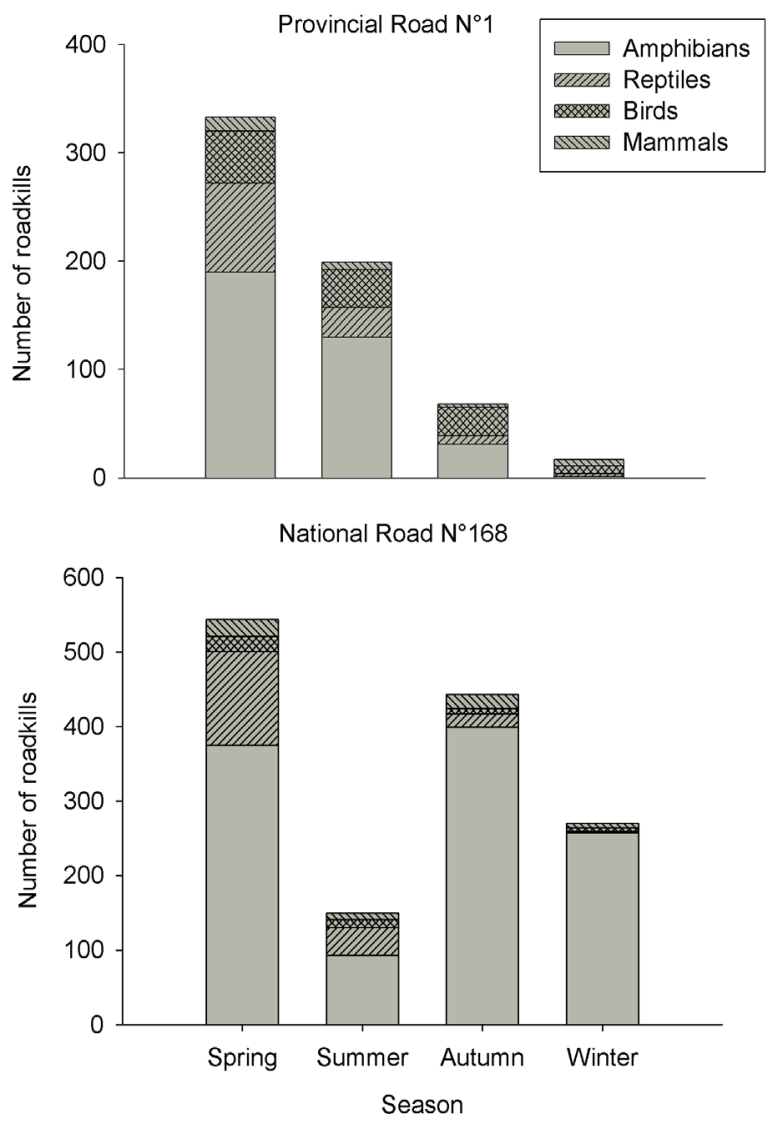

Figure 3. Seasonal abundance of vertebrates killed on 2 roads in Santa Fe Province, Argentina. 
$10 \mathrm{~km}$ from the study sites) to analyze their possible relation in vertebrate road kill patterns.

Data analysis. We tested differences in mortality among vertebrate classes by Chi-square probability tests. We analyzed the variation in abundance among species within each class (amphibians, reptiles, birds, and mammals) and total vertebrate species between roads (NR168 and PR1) using a Mann-Whitney-Wilcoxon test. Furthermore, we tested correlation between road kill numbers for each taxon with monthly mean temperature and monthly total precipitation levels using the Spearman's correlation test. We grouped months by season (evaluated factor): summer (January, February, and March), autumn (April, May, and June), winter (July, August, and September), and spring (October, November, and December). Seasonal variations were explored using a non-parametric Kruskal-Wallis test, followed by a Dunn post-hoc test (Zar, 1999). To compare vertebrate richness and diversity that differed in mortality number between roads we performed a rarefaction analysis. Rarefaction estimates the expected richness for a series of subsamples from the vertebrate abundance distribution (Gotelli and Graves, 1996). This analysis was performed to compare diversity (resulting from the sum of each vertebrate category from the 2 roads) using EcoSim (Gotelli and Entsminger, 2009). We constructed rarefaction curves (Hurlbert, 1971) using a Monte Carlo permutation method and rarefied samples to the smallest sample size. We tested these differences in richness and diversity (Shannon-index) using a MannWhitney-Wilcoxon test. For all tests, we considered significant a level of probability below 0.05 . Tests were performed with the programs PAST.exe (Hammer et al., 2001) and InFostat (1998).

\section{Results}

Road killed vertebrates. We collected 2024 specimens from 61 species ( 7 amphibians, 15 reptiles, 32 birds, and 7 mammals). All road killed individuals recorded were native species, except for 3 domestic species (Table 1). Vertebrate mortality differed significantly among vertebrate classes $\left(X^{2}=52.05, p<0.001\right)$. Amphibians were the most frequently recorded group $(n=1476$, $72.92 \%)$, followed by reptiles, $(n=303,14.97 \%)$, birds $(n=159,7.88 \%)$, and mammals $(n=86,4.25 \%)$. The toad Rhinella fernandezae was the most commonly killed species $(n=1307,64.57 \%)$, followed by Colubridae (non-identified $n=178,8.79 \%$ ), and Passeriformes nonidentified $(n=71,3.50 \%)$.

Road killed vertebrates in RN168 and PR1. We recorded 1 407 road killed vertebrates (39 individuals per kilometer) on NR168, whereas on PR1 we recorded 617 (17 ind $/ \mathrm{km})$.
We found a significantly higher abundance of road killed vertebrates on NR168 than on PR1 (Mann-WhitneyWilcoxon $W=119, p<0.05)$ for amphibians $(W=115.50$, $p<0.05$ ), whereas birds presented a higher abundance of road kills on PR1 than on NR168 ( $W=195.50, p<0.05)$. The difference in the number of road killed reptiles and mammals recorded between roads was not significant ( $W=140, p>0.05$ and $W=123.50, p>0.05$; respectively).

Rarefaction analysis (12 intervals, 10000 permutations) showed that richness $(\mathrm{R})$ and diversity $\left(\mathrm{H}^{\prime}\right)$ mortalities were different ( $W=193, p<0.05$ and $W=260, p<0.05$; respectively) between PR1 ( $\mathrm{R}=37 \pm 3$ and $\mathrm{H}^{\prime}=2.33 \pm$ $0.10)$ and $\mathrm{NR} 168\left(\mathrm{R}=26 \pm 2\right.$ and $\left.\mathrm{H}^{\prime}=1.21 \pm 0.07\right)$.

Environmental variables and temporal analysis. We observed a positive correlation between road killed vertebrate abundance with mean monthly air temperature $(r=0.82 ; p<0.05)$ and monthly total rainfall levels on PR1 $(r=0.86 ; p<0.05$; Fig. 2$)$; whereas on NR168 no relationships were detected $(r=0.21, p>0.05$ and $r=0.36 ; p>0.05)$. Moreover, regarding each class and the relationship with environmental variables we observed that amphibians, reptiles, and birds were positively correlated with temperature $(r=0.82, p<0.05$; $r=0.80, p<0.05 ; r=0.80, p<0.05$; respectively) and precipitation $(r=0.87, p<0.05 ; r=0.77, p<0.05$; and $r=0.65, p<0.05$; respectively) on PR1. We found significant differences between seasons on PR1 (Fig 3). Spring and summer were the seasons with the highest mortality for all groups (vertebrate Kruskal-Wallis $K S$ test $H=19.67, p<0.05$; amphibians $H=18.4, p<0.05$; reptiles $H=20.39, p<0.05$; and birds $H=8.01, p<0.05$ ), except for mammals $(H=2.11, p>0.05)$. We found no seasonal differences in mortality (Fig. 3) for total vertebrates $(H=3.62, p>0.05)$, amphibians $(H=2.59$, $p>0.05)$, birds $(H=5.99, p>0.05)$, or mammals $(H=$ $3.85, p>0.05)$ on NR168, excepted for reptiles $(H=9.98$, $p<0.05)$ in spring.

\section{Discussion}

Vertebrate mortality was high on the 2 roads studied (PR1 and NR168) of Santa Fe Province. Similarly, other authors (Fahrig et al., 1995; Ashley and Robinson, 1996; Gryz and Krauze, 2008) have reported comparable numbers of road-killed vertebrates in samplings involving shorter road stretches and periods. Considering all the road-killed vertebrates found in our study, amphibians and reptiles were the most affected groups. Likewise, Ashley and Robison (1996), Glista et al. (2008), and Shepard et al. (2008) observed that amphibians and reptiles were the animals that suffered the highest number of road kills in wetlands. In addition, Smith and Dodd (2003) counted 
Table 1. Absolute and relative abundances (\%, in parentheses) of vertebrates killed on PR1 (Provincial Road No. 1) and NR168 (National Road No. 168) in Santa Fe Province, Argentina

\begin{tabular}{|c|c|c|c|}
\hline$T A X A$ & PR1 & NR168 & Total \\
\hline \multicolumn{4}{|l|}{ AMPHIBIA } \\
\hline \multicolumn{4}{|l|}{ Bufonidae } \\
\hline Rhinella fernandezae & $244(39.55)$ & $1063(75.55)$ & 1307 (64.57) \\
\hline R. schneideri & $7(1.13)$ & $11(0.78)$ & $18(0.89)$ \\
\hline Rhinella sp. & $29(4.70)$ & $28(1.99)$ & $57(2.82)$ \\
\hline \multicolumn{4}{|l|}{ Leptodactylidae } \\
\hline Leptodactylus latrans & $33(5.35)$ & $8(0.57)$ & $41(2.02)$ \\
\hline L. gracilis & $2(0.32)$ & $1(0.07)$ & $3(0.15)$ \\
\hline Leptodactylus sp. & $20(3.24)$ & $6(0.43)$ & $26(1.28)$ \\
\hline \multicolumn{4}{|l|}{ Hylidae } \\
\hline Hypsiboas raniceps & $1(0.16)$ & - & $1(0.05)$ \\
\hline H. pulchellus & $16(2.59)$ & $5(0.35)$ & $21(1.04)$ \\
\hline Scinax nasicus & - & $2(0.14)$ & $2(0.10)$ \\
\hline Total amphibians & $352(57.05)$ & $1124(79.89)$ & $1476(72.92)$ \\
\hline \multicolumn{4}{|l|}{ REPTILIA } \\
\hline \multicolumn{4}{|l|}{ TESTUDINES } \\
\hline \multicolumn{4}{|l|}{ Chelidae } \\
\hline Phrynops hilarii & $4(0.65)$ & $19(1.35)$ & $23(1.14)$ \\
\hline \multicolumn{4}{|l|}{ SQUAMATA } \\
\hline \multicolumn{4}{|l|}{ Teiidae } \\
\hline Tupinambis merianae & $6(0.97)$ & $6(0.43)$ & $12(0.59)$ \\
\hline Teius teyou & - & $1(0.07)$ & $1(0.05)$ \\
\hline \multicolumn{4}{|l|}{ Anguidae } \\
\hline Ophiodes sp. & $7(1.13)$ & $21(1.49)$ & $28(1.38)$ \\
\hline \multicolumn{4}{|l|}{ Colubridae } \\
\hline Philodryas patagoniensis & $2(0.32)$ & $2(0.14)$ & $4(0.20)$ \\
\hline P. aestivus & - & $1(0.07)$ & $1(0.05)$ \\
\hline Liophis anomalus & $4(0.65)$ & - & $4(0.20)$ \\
\hline L. miliaris & $3(0.49)$ & $4(0.28)$ & $7(0.34)$ \\
\hline L. jaegeri & - & $1(0.07)$ & $1(0.05)$ \\
\hline Liophis sp. & $3(0.49)$ & $1(0.07)$ & $4(0.20)$ \\
\hline Helicops leopardinus & $3(0.49)$ & $4(0.28)$ & $7(0.34)$ \\
\hline Oxyrhopus rhombifer & - & $1(0.07)$ & $1(0.05)$ \\
\hline Thamnodynastes strigatus & - & $2(0.14)$ & $2(0.10)$ \\
\hline T. hypoconia & $1(0.16)$ & $8(0.56)$ & $9(0.44)$ \\
\hline Pseudotomodon trigonatus & - & $2(0.14)$ & $2(0.10)$ \\
\hline NI & $80(12.96)$ & $98(6.96)$ & $178(8.79)$ \\
\hline \multicolumn{4}{|l|}{ Viperidae } \\
\hline Bothrops alternatus & $7(1.13)$ & $12(0.85)$ & $19(0.94)$ \\
\hline Total reptiles & $120(19.45)$ & $183(12.99)$ & 303 (14.97) \\
\hline \multicolumn{4}{|l|}{ AVES } \\
\hline \multicolumn{4}{|l|}{ PELECANIFORMES } \\
\hline Phalacrocoracidae & & & \\
\hline
\end{tabular}


Table 1. Continues

\begin{tabular}{|c|c|c|c|}
\hline$T A X A$ & PR1 & NR168 & Total \\
\hline Phalacrocorax brasilianus & - & $1(0.07)$ & $1(0.05)$ \\
\hline \multicolumn{4}{|l|}{ COLUMBIFORMES } \\
\hline \multicolumn{4}{|l|}{ Columbidae } \\
\hline Columbina picui & - & $4(0.28)$ & $4(0.20)$ \\
\hline Columba livia & $1(0.16)$ & $3(0.21)$ & $4(0.20)$ \\
\hline Zenaida auriculata & - & $11(0.78)$ & $11(0.54)$ \\
\hline \multicolumn{4}{|l|}{ PSITTACIFORMES } \\
\hline \multicolumn{4}{|l|}{ Psittacidae } \\
\hline Melopcitacus undulatus * & - & $1(0.07)$ & $1(0.05)$ \\
\hline \multicolumn{4}{|l|}{ CUCULIFORMES } \\
\hline \multicolumn{4}{|l|}{ Cuculidae } \\
\hline Guira guira & $1(0.16)$ & - & $1(0.05)$ \\
\hline Coccyzus melacoryphus & - & $1(0.07)$ & $1(0.05)$ \\
\hline \multicolumn{4}{|l|}{ STRIGIFORMES } \\
\hline \multicolumn{4}{|l|}{ Tytonidae } \\
\hline Tyto alba & - & $2(0.14)$ & $2(0.10)$ \\
\hline \multicolumn{4}{|l|}{ Strigidae } \\
\hline Athene cunicularia & $3(0.49)$ & - & $3(0.15)$ \\
\hline \multicolumn{4}{|l|}{ APODIFORMES } \\
\hline \multicolumn{4}{|l|}{ Trochilidae } \\
\hline Chlorostilbon aureoventris & $1(0.16)$ & - & $1(0.05)$ \\
\hline \multicolumn{4}{|l|}{ PICIFORMES } \\
\hline \multicolumn{4}{|l|}{ Picidae } \\
\hline Picumnus cirratus & $1(0.16)$ & - & $1(0.05)$ \\
\hline Picoides mixtus & $1(0.16)$ & - & $1(0.05)$ \\
\hline Colaptes malanolaimus & - & $1(0.07)$ & $1(0.05)$ \\
\hline \multicolumn{4}{|l|}{ PASSERIFORMES } \\
\hline \multicolumn{4}{|l|}{ Dendrocolaptidae } \\
\hline Lepidocolaptes angustirostris & - & $1(0.07)$ & $1(0.05)$ \\
\hline \multicolumn{4}{|l|}{ Furnariidae } \\
\hline Furnarius rufus & $16(2.59)$ & $4(0.28)$ & $20(0.99)$ \\
\hline Certhiaxis cinnamomea & $1(0.16)$ & - & $1(0.05)$ \\
\hline \multicolumn{4}{|l|}{ Tyrannidae } \\
\hline Machetornis rixosus & $1(0.16)$ & - & $1(0.05)$ \\
\hline Tyrannus savana & $1(0.16)$ & - & $1(0.05)$ \\
\hline Pitangus sulphuratus & $4(0.65)$ & - & $4(0.20)$ \\
\hline \multicolumn{4}{|l|}{ Hirundinidae } \\
\hline Progne chalybea & $1(0.16)$ & - & $1(0.05)$ \\
\hline \multicolumn{4}{|l|}{ Troglodytidae } \\
\hline Troglodytes aedon & $1(0.16)$ & - & $1(0.05)$ \\
\hline Cistothorus platensis & $1(0.16)$ & - & $1(0.05)$ \\
\hline \multicolumn{4}{|l|}{ Turdidae } \\
\hline Turdus rufiventris & $2(0.32)$ & - & $2(0.10)$ \\
\hline Sylviidae & & & \\
\hline
\end{tabular}


Table 1. Continues

\begin{tabular}{|c|c|c|c|}
\hline TAXA & PRI & NR168 & Total \\
\hline Polioptila dumicola & $1(0.16)$ & $1(0.07)$ & $2(0.10)$ \\
\hline \multicolumn{4}{|l|}{ Emberizidae } \\
\hline Sicalis flaveola & $1(0.16)$ & $1(0.07)$ & $2(0.10)$ \\
\hline Sicalis luteola & $1(0.16)$ & - & $1(0.05)$ \\
\hline Paroaria coronata & $5(0.81)$ & - & $5(0.25)$ \\
\hline Paroaria capitata & $4(0.65)$ & $2(0.14)$ & $6(0.30)$ \\
\hline Saltator coerulescens & $1(0.16)$ & - & $1(0.05)$ \\
\hline Zonotrichia capensis & $3(0.49)$ & - & $3(0.15)$ \\
\hline Sporophila caerulescens & $1(0.16)$ & - & $1(0.05)$ \\
\hline Coryphospingus cucullatus & $1(0.16)$ & - & $1(0.05)$ \\
\hline \multicolumn{4}{|l|}{ Icteridae } \\
\hline Molothrus sp. & $1(0.16)$ & - & $1(0.05)$ \\
\hline NI & $61(9.89)$ & $10(0.71)$ & $71(3.50)$ \\
\hline Total birds & $116(18.77)$ & $43(3.03)$ & $159(7.88)$ \\
\hline \multicolumn{4}{|l|}{ MAMMALIA } \\
\hline \multicolumn{4}{|l|}{ DIDELPHIMORPHIA } \\
\hline \multicolumn{4}{|l|}{ Didelphidae } \\
\hline Didelphis albiventris & $9(1.46)$ & $6(0.42)$ & $15(0.74)$ \\
\hline \multicolumn{4}{|l|}{ CARNIVORA } \\
\hline \multicolumn{4}{|l|}{ Canidae } \\
\hline Cannis domesticus * & $3(0.49)$ & $3(0.21)$ & $6(0.30)$ \\
\hline Cerdocyon thous & - & $7(0.49)$ & $7(0.35)$ \\
\hline \multicolumn{4}{|l|}{ Felidae } \\
\hline Leopardus geoffroyi & - & $4(0.28)$ & $4(0.20)$ \\
\hline Felis catus $*$ & $1(0.16)$ & - & $1(0.05)$ \\
\hline \multicolumn{4}{|l|}{ CHIROPTERA } \\
\hline NI & $2(0.32)$ & $7(0.49)$ & $9(0.44)$ \\
\hline \multicolumn{4}{|l|}{ RODENTIA } \\
\hline \multicolumn{4}{|l|}{ Muridae } \\
\hline $\mathrm{NI}$ & $8(1.30)$ & $18(1.28)$ & $26(1.28)$ \\
\hline \multicolumn{4}{|l|}{ Caviidae } \\
\hline Cavia aperea & $1(0.16)$ & - & $1(0.05)$ \\
\hline NI mammals & $5(0.81)$ & $12(0.85)$ & $17(0.84)$ \\
\hline Total mammals & $29(4.70)$ & $57(4.03)$ & $86(4.25)$ \\
\hline Total Vertebrates & 617 & 1407 & 2024 \\
\hline
\end{tabular}

*domestic species

NI: non-identified

$>1800$ mortalities along a $3.2 \mathrm{~km}$ stretch of a highway in Florida, of which $91 \%$ represent the herpetofauna. In accordance with these authors, roads that traverse wetlands become major sources of amphibian and reptile mortality. However, birds and mammals may be affected by vehicle collisions on roads with different landscape composition. Cordero (2000) and Lesiński et al. (2010) found that in urban and suburban habitats, marsupials and bats are the main species of wild mammals killed on roads. In contrast, Bencke and Bencke (1999) observed a high mortality of birds in large forest areas.

Regarding species, we found that Rhinella fernandezae was the most abundant of all road-killed vertebrates. It is important to note that $R$. fernandezae is a sedentary toad that lives in burrows (Sanchez and Busch, 2008) and is frequently observed near the road 
surveyed. Taking into account its natural history and the results presented here, this species can be considered as the most vulnerable to the impact of roads due to its slow and long-distance movements (Contreras and Contreras, 1982). Furthermore, reptiles of the family Colubridae (colubrids) were the second most abundant group of road-killed vertebrates. Body degradation affected not only the absolute number of carcasses recorded, but also their identity. For this reason, some of the 178 Colubridae identified to family but not to species (Table 1) probably belonged to the genera Liophis, Helicops, and Thamnodynastes. These colubrids are typical of aquatic environments natural to the Paraná River and are frequent in the areas surrounding the studied roads (Arzamendia and Giraudo, 2002; Giraudo et al., 2004).

Accordingly, several factors inherent to each species might be involved in road kills, such as land use associated with roads (e.g., lakes, woodland), the speed of the movements of each species, population density in environments on each roadside, and species biological cycle (McClure, 1951; Bernardino and Dalrymple, 1992; Cupul, 2002; Steen and Gibbs, 2004; Aresco, 2005). Moreover, it is difficult to determine the real effect of roads on herpetofauna, since many species, even of amphibians, exhibit inter-annual variations. In this context, Fahrig et al. (1995) and Bonnet et al. (1999) showed that traffic has an important negative effect on local densities of amphibians and reptiles. Indeed, those authors stated that recent worldwide increases in traffic might have contributed to the documented global decline of these taxa, especially in urban areas. By contrast, Taylor and Goldingay (2004) reported opposite trends in north-eastern New South Wales, since the number of mammals killed on roads was higher than bird, reptiles, and amphibian road kills. It is important to note that a possible difference in the number of animal road kills resides in the methods of sampling. We conducted surveys only on foot, unlike other studies in which field data came via car driving surveys. The last method is questionable because some small animals could be underestimated (Langen et al., 2007) and therefore, it is not a reliable method for recording killed juvenile or adult amphibians.

On the other hand, the number of road killed vertebrates and the taxa affected differed between roads, with amphibians more represented onn RN168 and birds on PR1. These dissimilarities can be explained by the higher and more constant vehicle flow observed on NR168 than on PR1. According to Mazerolle (2004) and Orłowski and Nowak (2006), daily traffic volume (approximately an average of 10000 vehicles per hour) is considered the crucial factor affecting mortality abundance in small vertebrates (e.g., amphibians). Moreover, differences in abundance and composition of the assemblages at an intraregional scale and the management strategy used during the road widening process could also influence the number of dead animals. For instance, characteristics of the surrounding habitats, such as the presence of a large number of trees near roadsides, could explain high mortality of birds on a road of relatively low traffic flow (PR1). Such intraregional dissimilarities indicate the need for local evaluations of a single road or road stretches, instead of regional assessments, regarding the magnitude and composition of road mortality of native fauna (Glista et al., 2008).

Local environmental conditions (air temperature and rainfall) and seasons influenced vertebrate road kill (particularly, amphibians, reptiles, and birds) numbers in our study area. The highest number of road kills on PR1 occurred during spring and summer (the period of highest monthly mean temperatures and precipitation). An explanation of this pattern could be related to differences in vehicle traffic intensity observed in these periods (pers. obs.) and probably to the higher mobility and/or abundance of the fauna for reproduction and dispersal (Coelho et al., 2008; Glista et al., 2008). Likewise, these patterns may reflect spatial and temporal variations in environmental characteristics and availability of resources. These results are in agreement with previous studies that also found climate and season-related patterns, as they recorded higher number of road kills throughout the spring and summer months for amphibians and reptiles (Gibbons and Semlitsch, 1987; Bonnet et al., 1999; Smith and Dodd, 2003; Glista et al., 2008). Similarly, bird mortality was higher in spring and summer on this road. Hell et al. (2005) also observed a marked seasonal variation in bird road kills, with the highest records in summer and the lowest in winter. By contrast, we found no differences between vertebrate mortality and environmental variables (precipitation and temperature) or seasonality on RN168. The lack of seasonality and environmental relationship with vertebrate road mortalities observed on this road might be due to the widening work, which involved soil movement on the roadsides, producing disruption of the surrounding environments, which in turn resulted in species migrating or moving to other places and therefore being exposed to collisions. Accordingly, disturbances in roadside areas produce a greater increase of vertebrate species mortality (Forman and Alexander, 1998; Forman, 2000).

In general, the broad survey of road mortality described in the present study suggests that vertebrate road mortality is a very serious problem. In this sense, monitoring protocols must be established based on the taxonomic group of interest (Glista et al., 2008) and mitigation measures are needed (such as the construction 
of underpasses or of culvert and barrier wall systems). Our results emphasize that road kill may be a significant local factor in amphibian and reptile population fluctuations.

\section{Literature cited}

ANER. 2008. Agencia de noticias de Entre Ríos. http://www. apfdigital.com.ar; last access: 28.V.2009.

Aresco, M. J. 2005. The effect of sex-specific terrestrial movements and roads on the sex ratio of freshwater turtles. Biological Conservation 123:37-44.

Arroyave, M. P., C. Gómez, M. E. Gutiérrez, D. P. Múnera, P. A. Zapata, I. C. Vergara, L. M. Andrade and K. C. Ramos. 2006. Impactos de las carreteras sobre la fauna silvestre y sus principales medidas de manejo. Revista EIA 5:45-57.

Arzamendia, V. and A. R. Giraudo. 2002. Lista y distribución de los ofidios (Reptilia: Serpentes) de Santa Fe, Argentina. Cuadernos de Herpetología 16:15-32.

Ashley, E. P. and J. T. Robinson. 1996. Road mortality of amphibians, reptiles and other wildlife on the Long Point Causeway, Lake Erie, Ontario. Canadian Field Naturalist 110:403-412.

Bencke, G. A. and C. S. C. Bencke. 1999. The potential importance of road deaths as cause of mortality for large forest owls in southern Brasil. Cotinga, Bedfordshire 11:7980.

Bernardino, F. S. and G. H. Dalrymple. 1992. Seasonal activity and road mortality of the snakes of the Pahayokee wetlands of Everglades National Park, USA. Biological Conservation 62:71-75.

Blaustein, A. R. and D. B.Wake. 1990. Declining amphibian populations: a global phenomenon? Trends Ecological Evolution 5:203-204.

Bonnet, X., N. Guy and R. Shine. 1999. The dangers of leaving home. Dispersal and mortality in snakes. Biological Conservation 89:39-50.

Burkart, R., N. Bárbaro, R. O. Sánchez and D. A. Gómez. 1999. Ecorregiones del Argentina. Administración Parques Nacionales, Buenos Aires, Argentina. 43 p.

Cabrera, M. R. 1998. Las tortugas continentales de Sudamérica austral. Ediciones Independientes. Córdoba, Argentina. 108 p.

Cairo, S. L. and S. M. Zalba. 2007. Effects of a paved road on mortality and mobility of red bellied toads (Melanophryniscus sp.) in Argentinean grasslands. Amphibia-Reptilia 28:377-385.

Canevari, M. and C. Fernández Balboa. 2003. 100 Mamíferos Argentinos. Editorial Albatros. Buenos Aires. Argentina. $160 \mathrm{p}$.

Ceballos, G. and P. R. Ehrlich. 2002. Mammal population losses and the extinction crisis. Science 296:904-907.

Cei, J. M. 1980. Amphibians of Argentina. Monitore Zool. Ital (ns). Monografia 2:609 p.
Clarke, G. P., P. C. L. Whiteand and S. Harris. 1998. Effects of roads on badger Meles meles populations in south-west England. Biological Conservation 86:117-124.

Coelho, I. P., A. Kindeland and A. V. P. Coelho. 2008. Roadkills of vertebrate species on two highways through the Atlantic Forest Biosphere Reserve, southern Brazil. European Journal Wildlife Reserch 54:689-699.

Contreras, J. R. and A. N. Contreras 1982. Características ecológicas y biogeografías de la batracofauna del noroeste de la provincia de Corrientes, Argentina. Ecosur 9:29-66.

Cordero, R. G. 2000. The biology of the opossum (Didelphis marsupialis) in urbanized environments from Northern Venezuela. Acta Biologica Venezuelica 20:13-28.

Cupul, F. G. 2002. Víctimas de la carretera: fauna apachurrada. Gaceta CUC. Departamento de Ciencias. Centro Universitario de la Costa, México.

Das, A., M. F. Ahmed, B. P. Lahkarand and P. Sharma. 2007. A preliminary report of reptilian mortality on road due to vehicular movement near Kaziranga National Park, Assam, India. Zoos Print Journal 22:2742-2744.

DNRPA. 2001. Dirección nacional de los registros nacionales de la propiedad del automotor y créditos prendarios. http:// www.dnrpa.gov.ar; last access: 5.II.2010.

DNV. 2001 Dirección Nacional de vialidad. Evolución de la Red Nacional de Caminos. hpp://www.vialidad.gov.ar; last access: 15.II.2009.

El Litoral. 2008. El Túnel sirve al 65\% del tránsito con Entre Ríos. ttp://www.ellitoral.com/index.php/diarios/2009/07/30/ politica/POLI-01.html; last access: 11.IV.2009.

Erritzoe, J., T. D. Mazgajski and L. Rejt. 2003. Bird casualties on European roads--a review. Acta Ornithologica 28:77-93.

Fahrig, L., J. H. Pedlar, S. E. Pope, P. D. Taylorand and J. F. Wegner. 1995. Effect of road traffic on amphibian density. Biological Conservation 73:177-182.

Ferreras, P., J. J. Aldama, J. F. Beltránand and M. Delibes. 1992. Rates and causes of mortality in a fragmented population of Iberian lynx, Felis pardina (Temminck). Biological Conservation 61:197-202.

Forman, R. T. T. and L. E. Alexander. 1998. Roads and their major ecological effects. Annual Review of Ecology and Systematics 29:207-231.

Forman, R. T. T. 2000. Estimate of the area affected ecologically by the road system in the United States. Biological Conservation 14:31-35.

Foster, M. L. and S. R. Humphrey. 1995. Use of highway underpasses by Florida panthers and other wildlife. Wildlife Society Bulletin 23:95-100.

Gibbons, J. W. and R. D. Semlitsch. 1987. Activity patterns. In Snakes: ecology and evolutionary biology, R. A. Seigel, J. T. Collins and S. S. Novak (eds.). Macmillan, New York. p. 396-421.

Gibbons, J. W., D. E. Scott, T. J. Ryan, K. A. Buhlmann, T. D. 
Tuberville, B. S. Metts, J. L. Greene, T. Mills, Y. Leiden, S. Poppyand and C. T. Winne. 2000. The global decline of reptiles, déjà vu amphibians. BioScience 50:653-666.

Gibbs, J. P. and D. A. Steen. 2005. Trends in sex ratios of turtles in the United States: implications of road mortality. Biological Conservation 19:552-556.

Giraudo, A. R. and V. Arzamendia. 1997. Clave para identificación de serpientes (Reptilia: Serpentes) de la Provincia de Santa Fe. Natura Neotropicalis 28:1-14.

Giraudo, A. R., V. Arzamendia and M. S. López. 2004. Ofidios del litoral fluvial de Argentina (Reptilia: Serpentes): biodiversidad y síntesis sobre el estado actual de conocimiento. In Temas de la biodiversidad del Litoral Fluvial Argentino, F. G. Aceñolaza (ed.). Tucumán, Instituto Superior de Correlación Geológica (INSUGEO, Miscelánea 12). p. 323-330.

Glista, D. J., T. L. DeVault and J. A. Dewoody. 2008. Vertebrate road mortality predominantly impacts amphibians. Herpetological Conservation Biology 3:77-87.

Gotelli, N. J. and G. R. Graves. 1996. Null Models in Ecology. Washington DC: Smithsonian Institution Press. USA. 368 p.

Gotelli, N. J. and G. L. Entsminger. 2009. EcoSim: null models software for ecology, version 7. Acquired Intelligence Inc. and Kesey-Bear, Burlington Vermont U.S.A. http:// homepages.together.net/gentsmin/ecosim. htm

Gryz, J. and D. Krauze. 2008. Mortality of vertebrates on a road crossing the Biebrza Valley (NE Poland). European Journal of Wildlife Research 54:709-714.

Hammer, Ø., D. A. T. Harper and P. D. Ryan. 2001. PAST: Paleontological statistics software package for education and data analysis. Palaeontología Electrónica 4:1-9.

Hell, P., R. Plavý, J. Slamečka and J. Gašparík. 2005. Losses of mammals (Mammalia) and birds (Aves) on roads in the Slovak part of the Danube Basin. European Journal of Wildlife Research 51:35-40.

Hels, T. and E. Buchwald. 2001. The effect of road kills on amphibian populations. Biological Conservation 99:331-340.

Huijser, M. P. and P. J. M. Bergers. 2000. The effect of roads and traffic on hedgehog (Erinaceus europaeus) populations. Biological Conservation 95:111-116.

Hurlbert, S. H. 1971. The non-concept of species diversity: A critique and alternative parameters. Ecology 52:577-586.

InFostat, 1998. Grupo InfoStat. Estadística y Biometría, Facultad de Ciencias Agropecuarias, Universidad Nacional de Córdoba.

Jaeger, J. A. G., J. Bowman, J. Brennan, L. Fahrig, D. Bert, J. Bouchard, N. Charbonneau, K. Frank, B. Gruber and K. Tluk von Toschanowitz. 2005. Predicting when animal populations are at risk from roads: an interactive model of road avoidance behavior. Ecological Modelling 185:329-348.

Langen, T. A., A. Machniak, E. K. Crowe, C. Mangan, D. F.
Marker, N. Liddle and B. Roden. 2007. Methodologies for surveying amphibian and herpetofauna mortality on rural highways. Journal of Wildlife Management 71:1361-1368.

Lesiński, G., A. Sikora and A. Olszewski. 2010. Bat casualties on a road crossing a mosaic landscape. European Journal Wildlife Reserch (in press).

Matlack, G. R. 1994. Plant species migration in a mixedhistory forest landscape in eastern North America. Ecology 75:1491-1502.

Mazerolle, M. J. 2004. Amphibian road mortality in response to nightly variations in traffic intensity. Herpetologica 60:45-53.

McClure, H. 1951. An analysis of animal victims on Nebraska's highways. Journal of Wildlife Management 15:410-420.

Mckenna, D., K. Mckenna, S. Malcom and M. Berenbaum. 2001. Mortality of Lepidoptera along roadways in central Illinois. Journal of Lepidoptera Society 55:63-68.

Narosky, T. and D. Yzurieta. 1987. Guía para la identificación de aves de Argentina y Uruguay. Asociación Ornitológica del Plata. Buenos Aires. 345 p.

Newmark, W. D., J. I. Boshe, H. I. Sariko and G. K. Makumbule. 1996. Effects of a highway on large mammals in Mikumi National Park, Tanzania. African Journal of Ecology 34:15-31.

Orłowski, G. and L. Nowak. 2006. Factors influencing mammal roadkills in the agricultural landscape of south-western Poland. Polish Journal of Ecology 54:283-294.

Row, J. R., G. Blouin-Demersand and P. J. Weatherhead. 2007. Demographic effects of road mortality in black ratsnakes (Elaphe obsoleta). Biological Conservation 137:117-120.

Sanchez, L. C. and M. Busch. 2008. Population traits of the burrowing toad Rhinella fernandezae (Gallardo, 1957) (Anura, Bufonidae). Brazilian Journal of Biology 68:137-140.

Seibert, H. and J. H. Conover. 1991. Mortality of vertebrates and invertebrates on an Athens County, Ohio, Highway. Ohio Journal of Science 91:163-166.

Seshadri, K. S., A. Yadevand and K. V. Gururaja. 2009. Road kills of amphibians in different land use areas from Sharavathi river basin, central Western Ghats, India. Journal of Threatened Taxa 1:549-552.

Shepard, D. B., M. J. Dreslik, B. C. Jellenand and C. A. Phillips. 2008. Reptile road mortality around an oasis in the Illinois corn desert with emphasis on the endangered Eastern Massasauga. Copeia 2008:350-359.

Shwiff, S. A., H. T. Smith, R. M. Engeman, R. M. Barry, R. J. Rossmanith and M. Nelson. 2007. Bioeconomic analysis of herpetofauna raod-kills in a Florida State Park. Ecological Economics 64:181-185.

Smith, L. L. and C. K. Dodd. 2003. Wildlife mortality on U.S. highway 441 across Paynes Prairie, Alachua County, Florida. Florida Scientist 66:128-140.

Steen, D. A. and J. P. Gibbs. 2004. Effects of roads on the 
structure of freshwater turtle populations. Biological Conservation 18:1143-1148.

Stuart, S. N., J. S. Chanson, N. A. Cox, B. E. Young, A. S. L. Rodriguez, D. L. Fischman and R. W. Waller. 2004. Status and trends of amphibian declines and extinctions worldwide. Science 306:1783-1786.

Taylor, B. D. and R. L. Goldingay. 2004. Wildlife roadkills on three major roads in north-eastern New South Wales. Wildlife Research 31:83-91.

Trombulak, S. C. and C. A. Frissell. 2000. Review of ecological effects of roads on terrestrial and aquatic communities. Biological Conservation 14:18-30.

Zar, J.H. 1999. Biostatistical Analysis. Prentice-Hall, New Jersey. 717 p. 